\title{
Epidural Analgesia in Sheep and Goats: A Review of Recent Literature
}

\author{
Zuhair BANI ISMAIL* \\ Department of Veterinary Clinical Sciences, Faculty of Veterinary Medicine, Jordan University of \\ Science and Technology, P. O. Box: 3030, Irbid 22110 - Jordan. \\ *corresponding author: zuhair72@just.edu.jo \\ Bulletin UASVM Veterinary Medicine 73(2) / 2016, \\ Print ISSN 1843-5270; Electronic ISSN 1843-5378 \\ DOI:10.15835/buasvmcn-vm: 12078
}

\begin{abstract}
This study was carried out to review the current literature concerning recent advances in the techniques, drugs and drug combinations used to induce epidural analgesia in sheep and goats. Data bases such as PubMed, Scopus, Google Scholar were searched using key words such as small ruminant anesthesia, local anesthesia in ruminants, and epidural analgesia in sheep and goats to retrieve recently published articles in this subject. Only articles published between 2007 and 2016 were considered. Relevant references in the bibliographies of included articles were also retrieved for review. A total of 14 research papers ( 7 in sheep and 7 in goats) published in refereed journals between 2007 and 2016 were reviewed. The lumbosacral space was used in 9 and the first intercoccygeal space was used in one article. The most common drugs used to induce epidural analgesia in sheep and goats were $2 \%$ lidocaine with and without epinephrine, bupivacaine, ropivacaine, magnesium sulphate, xylazine, ketamine, and tramadol, methadone, and morphine. The results of these studies indicated adequate analgesia for surgical operations of the perineum could be safely concluded in sheep and goats using any of the discussed drugs or their combinations.
\end{abstract}

Keywords: epidural analgesia, sheep, goats

\section{INTRODUCTION}

Epidural analgesia is commonly used in sheep and goats during surgical interventions involving the perineal area, caudal udder and upper hind limbs (Skarda and Tranquilli, 2007; Khajuria et al., 2014). In small ruminants, the lumbosacral space is most commonly used in lateral recombency (Lemke and Dawson, 2000). The first coccygeal intervertebral space (Co1- Co2) can also be used but it is much harder to locate in small ruminants (Lemke and Dawson, 2000). Aseptic technique is usually required before the site is injected using a sterile 18G, $3.25 \mathrm{~cm}$ long hypodermic needle (Lemke and Dawson, 2000). The needle must be inserted through the skin in an angle and directed toward the base of the tail (Lemke and Dawson, 2000). Needle placement in the correct site is usually checked using the hanging drop technique. Insertion of the needle further may lead to penetration of the spinal canal with a sudden jerky movement of the animal indicating incorrect placement of the needle (Lemke and Dawson, 2000). Once the needle is correctly placed in the epidural space, the anesthetic is injected slowly. The anatomic extent of analgesia obtained following epidural injections is usually determined by the volume of injected drugs and position of the animal during the procedure (Lucky et al., 2007). Higher volumes and tilting the animal cranially will extend the analgesic effect toward the flank region in recumbent animals (Lucky et al., 2007). For surgeries of the perineal region, smaller volumes are usually required. 


\section{Research question}

Lidocaine (2\%) with and without epinephrine alone or in combination with other drugs is the most commonly used local anesthetic in sheep and goats to induce epidural analgesia (Lucky et al., 2007; Bigham et al., 2009; Khajuria et al., 2014). However, in recent literature, there have been several research articles evaluating the analgesic effects of other drugs and drug combinations with variable successful results. There are no systematic review articles in the current literature that summarize published findings regarding epidural analgesia in sheep and goats. Therefore, the objectives of this article were to systematically review the current literature concerning recent advances in the techniques, drugs and drug combinations used to induce epidural analgesia in sheep and goats.

Data bases such as PubMed, Scopus, and Google Scholar were used in this review. Key words used were small ruminant anesthesia, local anesthesia in ruminants, and epidural analgesia in sheep and goats. Only articles published between 2007 and 2016 were considered. In addition, relevant references in the bibliographies of chosen articles were also retrieved for review. Only research article using epidural injection of drugs were included. Data regarding the technique of epidural administration, drugs and drug combinations, dosages, species and breed, side effects and recommendations for application of various techniques were discussed.

\section{General outlook}

There were a total of 14 research papers $(7$ in sheep and 7 in goats) published in refereed journals between 2007 and 2016 that fitted the criteria set forth for review. The lumbosacral space was used in 13 and the first intercoccygeal space was used in one article. In sheep, the most common drugs used to induce epidural analgesia were $2 \%$ lidocaine with and without epinephrine, bupivacaine, magnesium sulphate, tramadol, ketamine, methadone, and morphine (Table 1). Combinations of drugs in sheep were lidocaine-epinephrine, lidocaine-xylazine, lidocaine-bupivacaine, ketamine-magnesium sulphate, lidocaine-tramadol, lidocaine-magensium sulphate, and bupivacaine-methadone.

In goats, the most common drugs were $2 \%$ lidocaine, bupivacaine, ropivacaine, magnesium sulphate, and tramadol (Table 2). Combinations of drugs in goats were lodocaine-tramadol, lidocainemagnesium sulphate, xylazine-ketamine, and ropivacaine-xylazine.

\section{Drugs used for epidural analgesia in sheep and goats \\ Lidocaine}

Lidocaine is an acetamide local anesthetic. Local anesthetics act by blocking signal conduction by altering the fast voltage-gated sodium channels at the neuronal cell membrane (Lemke and Dawson, 2000; Skarda and Tranquilli, 2007). The activity of local anesthetics is not specific to the sensory tracts and therefore, an undesired effect such as motor block or motor paralysis is a common side effect (Lemke and Dawson, 2000; Skarda and Tranquilli, 2007). Because of its short duration of action, supplemental analgesia using different drugs or re-administration of drugs during surgical operations is usually necessary (Lemke and Dawson 2000; Skarda and Tranquilli, 2007). Opioids and alpha- 2 adrenergic agonists are commonly used in combinations with lidocaine resulting in longer and adequate analgesia (Bigham and Shafiei 2008; Bigham et al., 2009; Dehkordi et al., 2012; Rostami and Vesal, 2012). In this study, lodocaine hydrochloride $(2 \% ; 2-5 \mathrm{mg} /$ $\mathrm{kg}$ ) was the most commonly used local anesthetic drug for epidural analgesia in sheep (Table 1) and goats (Table 2). Epinephrine is sometimes added to lidocaine to prolong its duration of action (Rostami and Vesal, 2012).

\section{Bupivacaine}

Bupivacaine is another amide type of local anesthetic. It is characterized clinically by a prolonged analgesic effect with lesser effect on motor functions of the limbs (Rostami and Vesal, 2012; Rayees et al., 2011; Singh et al., 2015). The usual dose range of bupivacaine in sheep and goats is 0.5 to $1.7 \mathrm{mg} / \mathrm{kg}$ of body weight.

\section{Ropivacaine}

Ropivacaine, a long-acting amino-amine local anesthetic agent was used alone or in combinations with other drugs in goats (Rayees et al., 2011; Khajuria et al., 2014a,b; Kuthiala and Choudhary, 2011; Singh et al., 2015). The dose ranges between 0.5 to $1 \mathrm{mg} / \mathrm{kg}$. Rayees et al., (2011) concluded that ropivacaine $(0.6 \mathrm{mg} / \mathrm{kg})$ alone induced excellent epidural analgesia without affecting the cardio-respiratory function in goats. 
Tab.1. Drugs and drug combinations used to induce epidural analgesia in sheep

\begin{tabular}{|c|c|c|c|}
\hline Drugs and Dosages & Location & Comments & Reference \\
\hline $\begin{array}{l}\text { Bupivacaine }(0.25 \% ; 0.5 \mathrm{mg} / \mathrm{kg}) \\
\text { Methadone }(1 \% ; 0.3 \mathrm{mg} / \mathrm{kg} \\
\text { Bupivacaine }(0.25 \mathrm{mg} / \mathrm{kg})- \\
\text { Methadone }(0.15 \mathrm{mg} / \mathrm{kg})\end{array}$ & L6-S1 & $\begin{array}{c}\text { Bupivacaine, methadone or a combination } \\
\text { of the } 2 \text { drugs provide adequate } \\
\text { perioperative analgesia for surgical } \\
\text { procedures in the flank and hind limbs } \\
\text { Mild to moderate motor block for all agents }\end{array}$ & $\begin{array}{c}\text { DeRossi et } \\
\text { al., } 2015\end{array}$ \\
\hline $\begin{array}{c}\text { Lidocaine }(2 \% ; 5 \mathrm{mg} / \mathrm{kg}) \\
\text { Lidocaine }(2 \% ; 5 \mathrm{mg} / \mathrm{kg}) \\
\text { - epinephrine }(5 \mu \mathrm{m} / \mathrm{ml}) \\
\text { Lidocaine }(2 \% ; 5 \mathrm{mg} / \mathrm{kg}) \\
\text { - Xylazine }(0.05 \mathrm{mg} / \mathrm{kg}) \\
\text { Bupivacaine }(0.5 \%, 1 \mathrm{mg} / \mathrm{kg})\end{array}$ & L6-S1 & $\begin{array}{c}\text { Faster onset of analgesia with lidocaine- } \\
\text { xylazinethan with bupivacaine } \\
\text { Shorter duration of analgesia } \\
\text { with lidocaine-xylazineompared } \\
\text { with lidocaine-epinephrine } \\
\text { No adverse }\end{array}$ & $\begin{array}{c}\text { Rostami and } \\
\text { Vesal, } 2012\end{array}$ \\
\hline
\end{tabular}

\begin{tabular}{c} 
Lignocaine $(2 \% ; 4 \mathrm{mg} / \mathrm{kg})$ \\
\hline Lignocaine $(2 \% ; 4 \mathrm{mg} / \mathrm{kg})$ \\
-adrenaline $(0.0005 \%)$ \\
Bupivacaine $(0.5 \% ; 1 \mathrm{mg} / \mathrm{kg})$
\end{tabular}

\begin{tabular}{|c|c|c|c|}
\hline $\begin{array}{l}\text { Bupivacaine }(0.5 \mathrm{mg} / \mathrm{kg}) \\
\text { Morphine }(0.1 \mathrm{mg} / \mathrm{kg}) \\
\text { Bupivacaine }(0.25 \mathrm{mg} / \mathrm{kg})- \\
\text { Morphine }(0.05 \mathrm{mg} / \mathrm{kg})\end{array}$ & L6-S1 & $\begin{array}{l}\text { Bupivacaine and morphine combination } \\
\text { resulted in superior analgesia of the } \\
\text { thorax and forelimbs bilaterally } \\
\text { Ventilatory depression and muscle } \\
\text { paralysis require proper management }\end{array}$ & $\begin{array}{l}\text { DeRossi et } \\
\text { al., 2012a }\end{array}$ \\
\hline Ketamine (2.5 mg/kg) & & Significantly longer duration of analgesia & \\
\hline $\begin{array}{l}\text { Magnesium sulphate }(100 \mathrm{mg}) \\
\text { Ketamine }(2.5 \mathrm{mg} / \mathrm{kg})- \\
\text { Magnesium sulphate }(100 \mathrm{mg}) \\
\end{array}$ & L6-S1 & $\begin{array}{c}\text { produced by ketamine-magnesium } \\
\text { sulphate than that produced by either } \\
\text { ketamine or magnesium sulphate alone } \\
\text { No significant side effects }\end{array}$ & $\begin{array}{l}\text { DeRossi et } \\
\text { al., 2012b }\end{array}$ \\
\hline $\begin{array}{c}\text { Tramadol (1 mg/kg) } \\
\text { Lidocaine (2\%; } 2.86 \mathrm{mg} / \\
\mathrm{kg}) \text { - Tramadol }(1 \mathrm{mg} / \mathrm{kg}) \\
\text { Lidocaine }(2 \% ; 2.86 \mathrm{mg} / \mathrm{kg})\end{array}$ & L6-S1 & $\begin{array}{l}\text { Tramadol produced significantly longer } \\
\text { duration of analgesia than lidocaine alone } \\
\text { and lidocaine-tramadol combination }\end{array}$ & $\begin{array}{c}\text { Habibian et } \\
\text { al., } 2011\end{array}$ \\
\hline $\begin{array}{c}\text { Lidocaine }(2 \%)-\quad \text { Magnesium } \\
\text { sulphate }(100 \mathrm{mg})\end{array}$ & L6-S1 & $\begin{array}{l}\text { Significantly longer duration of anesthesia } \\
\text { with lidocaine-magnesium sulphate } \\
\text { compared with lidocaine-distilled water } \\
\text { No significant side effects }\end{array}$ & $\begin{array}{l}\text { Bigham and } \\
\text { Shafiei, } 2008\end{array}$ \\
\hline
\end{tabular}

$\begin{array}{ccc}\text { S5-C1 } & \text { No significant difference between } & \text { Lucky et } \\ & \text { bupivacaine and lignocaine-adrenaline } & \text { al., 2007; } \\ \text { in terms of their analgesic effect } & \text { Rostami and } \\ & \begin{array}{c}\text { Drowsiness, tympany and shivering } \\ \text { were observed with bupivacaine }\end{array} & \text { Vesal, 2012 } \\ & \end{array}$

Khajuria et al., (2014a) compared two doses of ropivaciane for epidural analgesia in goats; a high dose $(1 \mathrm{mg} / \mathrm{kg}$ ) and a low dose $(0.5 \mathrm{mg} / \mathrm{kg})$. He concluded that the lower dose of ropivacaine did not produce adequate analgesia while using the higher dose satisfactory regional analgesia lasting for an approximately 60 minutes was achieved. However, severe and prolonged motor loss may preclude its use in clinical practice. In another study, Khajuria et al., (2014b) compared the effects of lignocaine $(4 \mathrm{mg} / \mathrm{kg})$ and ropivacaine (1 $\mathrm{mg} / \mathrm{kg}$ ) for epidural analgesia in goats. He concluded that both lignocaine and ropivacaine produced satisfactory regional anesthesia in goats undergoing laparoscopy. However, because goats did not regain hind limb motor motor activity for a long time after the operation was completed, they were no able to recommend the use of ropivacaine 
Tab. 2. Drugs and drug combinations used to induce epidural analgesia in goats

\begin{tabular}{|c|c|c|c|}
\hline Drugs and Dosages & Location & Comments & References \\
\hline $\begin{array}{c}\text { Lidocaine }(2 \% ; 2.86 \mathrm{mg} / \mathrm{kg}) \\
\text { Lidocaine }(2 \% ; 2.86 \mathrm{mg} / \\
\mathrm{kg}) \text {-Tramadol }(1 \mathrm{mg} / \mathrm{kg}) \\
\text { Tramadol }(1 \mathrm{mg} / \mathrm{kg}) \\
\end{array}$ & L6-S1 & $\begin{array}{l}\text { Faster and longer duration of analgesia } \\
\text { with tramadol and tramadol-lidocaine } \\
\text { combination than the other treatments } \\
\text { No significant side effects with tramadol }\end{array}$ & $\begin{array}{l}\text { Dehkordi et } \\
\text { al., } 2012\end{array}$ \\
\hline $\begin{array}{l}\text { Tramadol (3 mg/kg) } \\
\text { Lignocaine (4 mg/kg) }\end{array}$ & L6-S1 & $\begin{array}{l}\text { Epidural tramadol produced partial pain } \\
\text { relief, while epidural lignocaine injection } \\
\text { provided the most effective pain control. } \\
\text { Lesser motor blockade with tramadol }\end{array}$ & $\begin{array}{l}\text { Ajadi } e t \\
\text { al. } 2012\end{array}$ \\
\hline $\begin{array}{l}\text { Ropivacaine }(1 \mathrm{mg} / \mathrm{kg}) \\
\text { Ropivacaine }(0.5 \mathrm{mg} / \mathrm{kg})\end{array}$ & L6-S1 & $\begin{array}{l}\text { Adequate analgesia with high dose } \\
\text { Analgesia extended up to } \\
\text { the umbilical region } \\
\text { Prolonged motor loss precludes its use } \\
\text { Inadequate analgesia with lower dose } \\
\end{array}$ & $\begin{array}{l}\text { Khajuria et } \\
\text { al., 2014a }\end{array}$ \\
\hline $\begin{array}{l}\text { Ropivacaine ( } 1 \mathrm{mg} / \mathrm{kg}) \\
\text { Lignocaine ( } 4 \mathrm{mg} / \mathrm{kg})\end{array}$ & L6-S1 & $\begin{array}{l}\text { Complete analgesia of the hind quarters } \\
\text { and abdomen in both treatments } \\
\text { Ropivacaine produced prolonged hind } \\
\text { limb motor loss which precludes its use }\end{array}$ & $\begin{array}{l}\text { Khajuria et } \\
\text { al., 2014b }\end{array}$ \\
\hline
\end{tabular}

Ropivacaine $(0.6 \mathrm{mg} / \mathrm{kg})$

Bupivacaine $(0.5 \mathrm{mg} / \mathrm{kg})$

Xylazine $(0.025 \mathrm{mg} / \mathrm{kg})-$

Ketamine $(2.5 \mathrm{mg} / \mathrm{kg})$

$$
\begin{gathered}
\text { Bupivacaine }(1.7 \mathrm{mg} / \mathrm{kg}) \\
\text { Ropivacaine }(0.6 \mathrm{mg} / \mathrm{kg}) \\
\text { Ropivacaine }(0.6 \mathrm{mg} / \mathrm{kg}) \\
\text {-Xylazine }(0.5 \mathrm{mg} / \mathrm{kg})
\end{gathered}
$$

L6-S1

Lidocaine $(2 \% ; 2.86 \mathrm{mg} / \mathrm{kg})$ Magnesium sulphate $(100 \mathrm{mg})$
All treatments produced adequate analgesia of the tail, perineum, inguinal region and thighs Analgesia was of longer duration and greater extent with xylazineketamine combination Singh et Mild sedation with xylazineketamine combination No significant side effects

Faster onset of analgesia with ropivacaine - xylazine combination Longer duration with ropivacaine No significant side effects

Rayees et al., 2011

Faster and longer duration of analgesia Bigham et No significant side effects al., 2015

al., 2009

at the suggested dose rate for epidural in goats. In comparison with bupivaciane and xylazine epidural in goats, Singh et al., (2015) found that ropivacaine $(0.6 \mathrm{mg} / \mathrm{kg})$ produced faster onset but lower quality analgesia of the tail and perineal regions (Sighn et al., 2015).

\section{Magnesium sulphate}

Following parenteral administration to animals, magnesium sulphate exerts an antinociceptive effect (Sirvinskas and Laurinaitis, 2002). The analgesic effects of magnesium sulphate are believed to be due its calcium antagonistic effects and also due to its antagonistic effect on N-methyl- d-aspartate (NMDA) receptors (Sirvinskas and Laurinaitis, 2002). In sheep and goats, magnesium sulphate had been experimented at a dose rate of $100 \mathrm{mg}$ to induce causal analgesia alone or in combination with lidocaine (Bigham et al., 2009; Bigham and Shafiei, 2008), and ketamine (DeRossi et al., 2012b). In sheep and goats, magnesium sulphate produced adequate analgesia of long duration for most obstetrical and surgical operations without the need for readministration of the anesthetic agent (Bigham and Shafiei, 2008; Bigham et al., 2009). In sheep, the co-administration of magnesium sulphate 
with ketamine produced analgesia that extended cranially to the regions of the dorsocaudal ribs, upper and lower flanks, upper hind limbs, and perineal and feet areas (DeRossi et al., 2012b). The combination however, produced severe motor block and ataxia of the hind limbs while when magnesium sulphate was administered alone it had no effect on the motor system in any of the sheep (DeRossi et al., 2012b).

\section{Ketamine}

Ketamineisan N-methyl-D-aspartatereceptors antagonist. It specifically blocks the sodium ion channels in the spinal cord. It also interacts with opioid, monoaminergic and muscarinic receptors and voltage-sensitive calcium ion channels (DeRossi etal., 2012b). The epidural administration of ketamine $(2.5 \mathrm{mg} / \mathrm{kg})$ alone or in combination with magnesium sulphate was evaluated in sheep (DeRossi et al., 2012b). The results showed that the combination is an effective and feasible and can be used safely in sheep. The only concern when ketamine is used however, either alone or in combinations is that it produces moderate to severe ataxia and precautionary measures must be taken in order to protect the animal. Ketaminexylazine combination is commonly used in goats for epidural analgesia. In the study by Singh et al., (2015), the combination produced analgesia of a greater extent and longer duration than that produced by bupivacaine and ropivacaine. However, mild sedation was noticeable in animals that received this combination (Singh et al., 2015).

\section{Xylazine}

Xylazine is an alpha- 2 agonist that produces its analgesic effect by stimulating the alpha-2 adrenergic receptors in the dorsal horn of the spinal cord (Singh et al. 2015). In sheep and goats, xylazine has been administered epidurally in combination with other drugs such as lidocaine (Rostami and Vesal, 2012), ketamine (Singh et al. 2015) and ropivaciane (Rayees et al., 2011). Xylazine is used at a dose rate of $0.025 \mathrm{mg} / \mathrm{kg}$ to $0.5 \mathrm{mg} / \mathrm{kg}$ of body weight. Usually, $2 \%$ solution is used in small ruminants. In sheep, Rostami and Vesal, (2012) concluded that the epidural administration of lidocaine-xylazine combination provides an adequate surgical analgesia of good duration without any adverse effects. In goats, a combination between ropivacaine and xylazine was evaluated as an epidural analgesic; combination was characterized by fast onset and long duration when compared with bupivacaine (Rayees et al., 2011). In addition, it was concluded that ropivacaine-xylazine combination had a synergistic analgesic effect (Rayees et al., 2011).

\section{Tramadol}

Tramadol is a synthetic analogue of codeine (Dehkordi et al., 2012). The mechanism of action of tramadol is attributed to its interaction with opioid $\mu$ receptors in the brain and spinal cord. It also modulates the mono-aminergic spinal pain by inhibiting the re-uptake of norepinephrine and serotonin (Dehkordi et al., 2012). Tramadol has been used for epidural analgesia in lambs and in goats alone and in combination with lidocaine or lignocaine (Habibian et al., 2011; Ajadi et al., 2012; Dehkordi et al., 2012). Dehkordi et al. 2012 and Habibian et al., 2011 compared the analgesic effect of lidocaine $(2.86 \mathrm{mg} / \mathrm{kg})$, lidocainetramadol (1 mg/kg and $2.46 \mathrm{mg} / \mathrm{kg}$ respectively) and tramadol alone $(1 \mathrm{mg} / \mathrm{kg})$ in adult goats and lambs respectively. Tramadol produced a significantly faster and longer duration of analgesia than tramadol-lidocaine combination or lidocaine alone. In addition, goats that received tramadol alone were the least as ataxic as the goats in the other two groups. In Ajadi et al., (2012) study, epidural tramadol was found to produce partial pain relief, while epidural lignocaine injection provided the most effective pain control. However, tramadol was advantageous over lignocane in that animals that received tramadol remained standing and ruminating while those received lignocaine became recumbent and stopped ruminating (Ajadi et al., 2012).

\section{Methadone and morphine}

Methadone and morphine are commonly used opioids agonists for perioperative pain management in animals and human patients undergoing various surgical procedures (DeRossi et al., 2012a, DeRossi et al., 2015). Opioids agonists selectively block sensory fibers, and thus provide useful analgesia with minimum risk of hind limb dysfunction. However, they may induce significant cardiovascular and pulmonary depression (DeRossi et al., 2012a, DeRossi et al., 2015). In sheep, methadone alone or in combination with bupivacaine for epidural analgesia was evaluated by DeRossi et al., (2015). Their results suggested the epidural administration of bupivacaine, methadone or the combination of both drugs provided adequate and useful perioperative analgesia in sheep undergo- 
ing various surgical procedures of the flank and hind limbs.

This is the first systematic review article concerning recent advancements of epidural analgesia in sheep and goats. In the last 10 years, 14 articles were found ( 7 in sheep and 7 in goats). In general, these articles investigated and compared the onset, duration, and extent of analgesia produced by various drugs and drug combinations in specific dose ranges. In addition, the degree of systemic sedative effects and motor blockade of the hind limbs were also assessed using various drugs and drug combinations. Most of the investigated drugs at the specified doses produced adequate analgesia of the perineal region with minimal side effects. The exception was ropivacaine in goats that was found to have a prolonged recovery that precluded its use in clinical practice especially when used in the higher dose $(1 \mathrm{mg} / \mathrm{kg})$. We here present the clinical practitioner with a list of options for use to induce safe and practical analgesia techniques in sheep and goats for surgical interventions of the tail, perineum, caudal udder and upper hind limbs. In another study, the combination of bupivaciane and morphine was evaluated in sheep after epidural injection (DeRossi et al., 2012a). Researchers found that the epidural administration of both drugs resulted in superior analgesia of the thoracic and forelimbs region in conscious sheep than either drug alone. Side effects such as depressed ventilation and muscle paralysis occurred and required appropriate management (DeRossi et al., 2012a).

The lumbosacral intervertebral space is the most common site for epidural injection of analgesic drugs in sheep and goats. The most common analgesic drugs for use for epidural injection in sheep and goats are lidocaine, bupivacaine, ropivacaine, magnesium sulphate, ketamine, xylazine, and tramadol.

\section{REFERENCES}

1. Ajadi RA, Owanikin AO, Martins MM, Gazal OS (2012). Effect of epidural tramadol and lignocaine on physiological and behavioural changes in goats subjected to castration with a high tension band. N Z Vet J 60: 344-348.

2. Bigham AS, Shafiei Z (2008). Comparison of caudal epidural anesthesia with lidocaine- distilled water and lidocaine-magnesium sulfate combination in sheep. Bulg J Vet Med 11:125-130.

3. Bigham AB, Shafiei Z, Nazhvani SD (2009). Comparison of epidural anesthesia with lidocaine-distilled water and lidocaine-magnesium sulfate mixture in goat. Vet Arhiv 79: 11-17.
4. Dehkordi SH, Bigham AS, Gerami R (2012). Evaluation of anti-nociceptive effect of epidural tramadol, tramadollidocaine and lidocaine in goats. Vet Anesth Analg 39: 106-110.

5. DeRossi R, Jardim P, Hermeto L, Pagliosa R (2015). Comparison of analgesic and systemic effects of bupivacaine, methadone, or bupivacaine/methadone administered epidurally in conscious sheep. Aust Vet J 93: 164-169.

6. DeRossi R, Pagliosa R, Módolo TC, Maciel FB, Macedo GG (2012a). Thoracic epidural analgesia via the lumbosacral approach using multiport catheters with a low concentration of bupivacaine and morphine in sheep. Vet Anesth Analg 39: 306-314.

7. DeRossi R, Pompermeyer CTD, Silva-Neto AB, Correa de Barros AL, Jardim PH, Frazílio FO (2012b). Lumbosacral epidural magnesium prolongs ketamine analgesia in conscious sheep. Acta Cir Bras 27: 137-143.

8. Habibian S, Bigham AS, Aali E (2011). Comparison of lidocaine, tramadol, and lidocaine-tramadol for epidural analgesia in lambs. Res Vet Sci 91: 434-438.

9. Khajuria A, Fazili MR, Shah RH, Khan FA, Bhat MH, Yaqoob DH, Naykoo NA, Ganai NA (2014a). Comparison of two doses of ropivacaine hydrochloride for lumbosacral epidural anaesthesia in goats undergoing laparoscopy assisted embryo transfer. Int Sch Res Notices Art. ID 937018, 8 pages.

10. Khajuria A, Fazili MR, Shah RH, Khan FA, Bhat MH, Yaqoob DH, Naykoo NA, Ganai NA (2014b). Comparison between lignocaine hydrochloride and ropivacaine hydrochloride as lumbosacral epidural anesthetic agents in goats undergoing laparoscopy assisted embryo transfer. Mac Vet Rev 37, 141-149.

11. Lemke KA, Dawson SD (2000). Local and regional anesthesia. Vet Clin North Am Small Anim Pract 30: 839-57.

12. Lucky NS, Hashim MA, Ahmed JU, Sarker K, Gazi NM, Ahmed S (2007). Caudal epidural analgesia in sheep by using lignocaine hydrochloride and bupivacaine hydrochloride. Bang J Vet Med 5: 77-80.

13. Kuthiala G, Choudhary G (2011). Ropivacaine: A review of its pharmacology and its clinical use. Ind J Anesth 55: 104-110.

14. Rayees A, Shukla BP, Jain R (2011). Clinicophysiological changes following epidural analgesia by bupivacaine, ropivacaine or ropivacaine-xylazine combination in goats. Ind Jf Vet Surg 32: 57-58.

15. Rostami M, Vesal N (2012). The effects of adding epinephrine or xylazine to lidocaine solution for lumbosacral epidural analgesia in fat-tailed sheep. J S Afr Vet Assoc 83, Art. \#1, 7 pages.

16. Skarda RT, Tranquilli WJ (2007). Local and regional anesthetics and analgesic techniques: ruminants and swine. In: Lumb \& Jones' Veterinary Anesthesia and Analgesia, 4th edn, pp. 643-681, Blackwell Publishing, Ames, IA, USA.

17. Singh K, Kinjavdekar P, Gopinathan A, Aithal HP, Amarpal (2015). Evaluation of ropivacaine, bupivacaine and xylazineketamine combination for epidural analgesia in goats. Vet Arhiv 85: 151-162.

18. Sirvinskas E, Laurinaitis R (2002). Use of magnesium sulfate in anesthesiology. Medicine 38: 147-50. 